\title{
22 An Investigation of Sustainable Yogic Agriculture as a Mind- Matter Farming Approach
}

\author{
Janus Bojesen Jensen \\ Coventry University
}

\section{CONTENTS}

Introduction: A Paradigm Shift for Farming Practice? ............................................................. 247

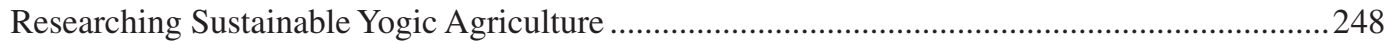

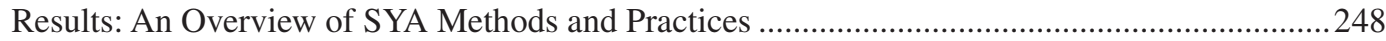

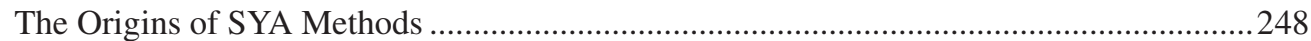

The Metaphysical Component: Practice of Raja Yoga Meditation.....................................249

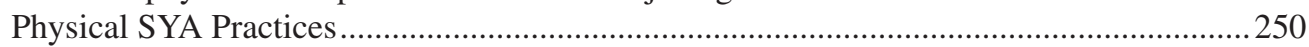

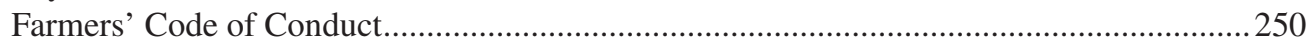

What Are the Impacts of SYA Farming Methods? ...........................................................250

Results of Published Research Trials on the Impacts of SYA .................................250

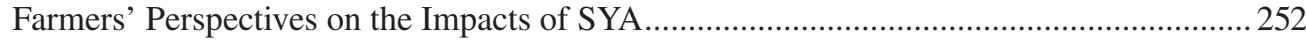

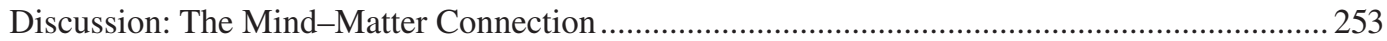

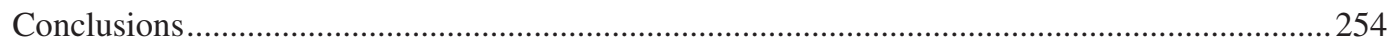

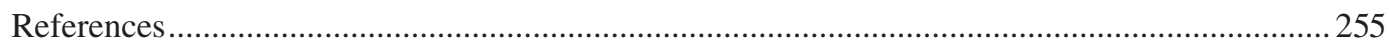

\section{INTRODUCTION: A PARADIGM SHIFT FOR FARMING PRACTICE?}

The global convergence of ecological, political, social and economic crises demands that 'business as usual' cannot continue. The global environmental and human health problems resulting from industrial-chemical agriculture have not gone away and are increasingly apparent in the public domain (IPCC, 2019; IARC, 2015; UNCTAD, 2013; UNCCD, 2011). Proposals from within the dominant paradigm that advocate further techno-fixes are no longer convincing or appropriate; as author Charles Eisenstein states, we are living in a liminal time 'between stories' (Eisenstein, 2013: 6). From an epistemological perspective, Santos (2014: 233) argues that global social justice is impossible without global cognitive justice and that we are in a transition period in which the problems created from the cultural and political confines of Western modernity have no modern solutions.

The alleged universal norms of modern industrial society, with its overriding emphasis on materialist science and technology as a means to subjugate nature, are a lingering Western colonial legacy. The ontological and epistemological premises of materialism continue to be challenged on the periphery by indigenous cultures, for example in the academic literature on decolonisation. Santos (2014: 188) refers to an existing 'sociology of absences' and calls for an 'ecology of knowledges' that enables alternate ways of knowing and scientific knowledge to coexist. The intimate connection between spirit and matter has long been recognised in the spiritual traditions and worldviews of indigenous cultures worldwide (Aikenhead and Michell, 2011; Ramsay, 2012a) and remains so in the world's social majority (Apffel-Marglin, 2012). In recent decades, the growing field of quantum 
mechanics within the Western scientific establishment reveals synergies with indigenous worldviews on the underlying nature of reality (Craven and I'poyi, 2009).

In the farming context, the application of invisible, non-material and spiritual practices is neither a radical nor a new suggestion. For over 10,000 years of farming, such practices were incorporated into agricultural life up until very recent times even in the West (Bellwood, 2005). The proposition of this chapter is that part (at least) of any transition towards a more healthy and regenerative global agriculture will not be found within the confines of the Western industrial worldview and its dogmas need to be overcome so as to include invisible, non-material and spiritual practices to supplement and perhaps alter the existing material ones.

\section{RESEARCHING SUSTAINABLE YOGIC AGRICULTURE}

One farming approach that recognises and works with the invisible, non-material dimension is Sustainable Yogic Agriculture (SYA). This system originates from the Brahma Kumaris spiritual movement, founded in India by Dada Lekhraj Kripalani in 1937, and which now has a global presence with 8,500 centres in 110 countries (Brahma Kumaris, ND). The Brahma Kumaris worldview is derived from Vedic cosmology and holds that all human beings are pure souls inhabiting a physical body. It states that soul consciousness, having traits of purity, bliss and love, is to be considered as one's true nature rather than the more common body consciousness, the latter being the cause of humanity's present afflictions (Ramsay, 2012b). The SYA initiative was launched in 2008 by the Rural Development Wing of the Brahma Kumaris World Spiritual University (RDW, 2009). SYA is premised on the philosophy that 'as the food, so the mind and as the mind, so the body'.

Given that SYA is little known as a farming system, a research study was developed to understand its methods and to ascertain its performance and potential. This was undertaken through a literature review followed by a field trip to SYA farmers in Rajasthan and Gujarat provinces, close to the Headquarters of the Brahma Kumaris at Mount Abu from 8 to 23 November 2017. Permission was necessarily obtained from the headquarters. Taking an inductive approach, the study assessed the findings against existing scientific evidence about the practices being performed.

In terms of scientific literature, only one peer-reviewed paper has been published on SYA (Pandey et al., 2015). Because of this dearth of research, non-peer-reviewed and grey literature is also taken into account in this chapter, including a further 12 publications that were only accessible in hard copy form at the Brahma Kumaris Headquarters.

The field study visit comprised a group interview based on a pre-prepared, semi-structured questionnaire that was conducted with eight farmers practising SYA. A translator was present to enable the discussion. This meeting was organised by the Brahma Kumaris Rural Development Wing, which also selected the participants, all of whom were members of a Gujarat-based SYA group consisting of 30 farmers. All were male and in an age range of between 40 and 60. The area of the farmers' holdings dedicated to SYA was small, averaging 1 acre, and did not cover all of their landholdings.

A field visit was also made to the Brahma Kumaris Demonstration Farm, 'Tapovan', located near the global headquarters at Shantivan, Mount Abu. This 5-acre horticultural farm has been managed as an SYA demonstration farm for the past 3 years, hosting educational visits by thousands of conventional small- and medium-scale farmers from within India and abroad.

Using an ethnographic approach, questions were put to the farm manager and a representative from the Rural Development Wing.

\section{RESULTS: AN OVERVIEW OF SYA METHODS AND PRACTICES}

\section{The Origins of SYA Methods}

SYA came into being as a result of observations by Indian farmers practising meditation in their fields to improve crop health. Their methods were brought to the attention of the Brahma Kumaris 
Rural Development Wing (RDW), which subsequently developed and launched them as an initiative to improve the lives and livelihoods of farmers (Ramsay, 2012a). Ramsay (2012a: 118) defines SYA as 'a unique form of farming that combines thought-based meditative practices with the methods of organic agriculture'. SYA sets its foundation on standard organic principles that prohibit the use of non-organic fertilisers and biocides. The metaphysical or subtle element of meditation is subsequently added as a core component of all farming practices throughout the year.

\section{The Metaphysical Component: Practice of Raja Yoga Meditation}

SYA farmers are firstly trained in the practice of Raja Yoga, a style of open-eyed meditation taught by the Brahma Kumaris that is inspired by ancient Indian practices. The method is described in the SYA Manual (RDW, 2009: 21-22) and summarised as follows:

The first step of Raja Yoga Meditation is to attain the soul-conscious stage. Pure thoughts are the source of pure vibrations, and pure vibrations create a pure atmosphere. After having entered into such a state, if you think positive about any person, animal, or vegetation irrespective of where they are, very far or very close, our vibrations reach them and activate every gene.

The manual also states that the ideal time to perform this meditation is between 4 and 5 am (part of the time period referred to as 'Amrit Vela'). Farmers should also transmit positive intentions outside this time period during specific farming activities. These regular meditation sessions can be conducted remotely or in the field, with focused thought practices and affirmations to support each phase of the crop growth cycle, from sowing, irrigation and growth to harvest and soil rehabilitation (Ramsay, 2012c; RDW, 2009). As well as focused meditation on the field crops, Ramsay (2012c) describes the practice of seeds being taken to local Brahma Kumaris meditation centres where experienced meditators focus thoughts of peace, non-violence, love, strength and resilience on them from between 10 days and 1 month prior to sowing. This is believed to enhance seed germination.

Examples of meditative affirmations for various stages and occurrences over the seasonal farming cycle are provided by Ramsay (2013a) and shown in Table 22.1.

Farmers are also encouraged to play music and sing spiritual songs while working in the fields, both for their own motivation and happiness and in the expectation that this will aid crop growth (RDW, 2009: 44). The ringing of bullocks' bells was also felt to have a beneficial environmental effect (farm group interview, this study). Another cultural practice is the hoisting of red and yellow 'Flag of Shiva' $5 \mathrm{ft}$ above the ground at regular intervals across the fields. This serves multiple purposes, some of which are metaphysical: it is a constant reminder to the farmer that he/she is tending God's land, and that the land is under divine care even when the farmer is not present; and it acts as a reflector of sunlight onto the crops (RDW, 2009: 44).

TABLE 22.1

\section{Affirmations Used by SYA Farmers at Specific Farming Events}

\section{Farming Event}

Amrit Vela (4-5 am every morning)

Ploughing the land

Application of organic inputs

Irrigating

Incidence of disease

Incidence of pests

\section{Affirmation}

I am the form of peace, filling seeds with peace

I am a soul who transforms the world

I bestow fortune on the earth

I am a living river of wisdom

I am the form of silent healing power

I am the form of supreme purity

Source: Ramsay (2013a). 
In the event of pest damage, farmers in the group interview explained that a farmer may enter a state of meditation with the aim of achieving pure soul consciousness. This feeling of soul purity is then vibrated onto the crop as being full of health and divine light and therefore capable of resisting the pests. On Tapovan farm, a case was reported where parrots were causing partial damage to fruits, and the farmer meditated and established a communication with the parrots, inviting them to eat some whole fruits and to leave others intact. This was reportedly successful. SYA was premised on the notion that the farm is not only for human beings but that animals and all other living things should also be accepted and have their rightful place on the farm.

While the SYA farmers in the group interview reported following the astrological calendar as part of their cultural tradition, Tapovan farm respondents explained that meditation rather than external influences was considered the primary force for ensuring crop health. Nevertheless, the SYA farmers felt that performing the meditation and sending love to distressed plants supported the use of traditional remedies, which, according to them, were generally effective.

According to respondents at Tapovan farm, the aim of teaching Raja Yoga meditation is to cultivate in farmers a feeling of connection to God, Self, the Motherland and cows - the holy animal of India, and that this inner transformation of the farmer will in turn transform the farm through right thinking and action. The early morning meditation takes place near the 'Flag of Shiva', which is hoisted in the field, and the visible results of the meditation typically manifest in around 2-3 months.

\section{Physical SYa Practices}

As well as meditation and focused intent, organic farming techniques are applied. These include companion planting and integrated pest management (RDW, 2009). Such techniques were visible on Tapovan farm alongside rotations and the use of green manures. From a physical perspective, the red and yellow 'Flag of Shiva' also acts as a deterrent to grasshoppers, which allegedly lay eggs on the yellow part of the flag and subsequently perish (RDW, 2009: 44).

The production of home-made farm inputs is encouraged, and the SYA Manual provides instructions on how to prepare 11 specific soil, bacterial inoculation, pest management and fungicide preparations based on traditional practices using cow by-products and other local materials (RDW, 2009: 31-24). One such preparation is 'Jeevamrut', an organic liquid fertiliser. Farmers in the group interview concurred that it was vital to have a healthy soil with a good carbon content and microbial population, and this was attained through composted cow manure, cover crops and 'Jeevamrut' that serves as an inoculate of beneficial microbes.

Farmers explained that the use of tractors should be avoided as these compact the soil and that bullocks should be used instead, which are gentler to 'Mother Earth' (farmer group interview). The Brahma Kumaris believe that cows are integral to agriculture. Nevertheless, a tractor was used on the demonstration SYA farm as it was under pressure to produce food for the thousands of visitors to the Mt. Abu Headquarters (Tapovan farm).

\section{Farmers' Code of Conduct}

As well as the metaphysical and physical farming practices, SYA also comprises a specific code of conduct for farmers. This includes adherence to a pure vegetarian diet, the practice of abstinence from carnal desires, the avoidance of drugs and alcohol, goodwill towards others, remembrance of God and the early morning meditations (RDW, 2009: 44).

\section{What Are the Impacts of SYa Farming Methods?}

\section{Results of Published Research Trials on the Impacts of SYA}

According to Ramsay (2012c), the first SYA field trials were launched in India in 2009 by the Brahma Kumaris Spiritual University, involving 400 farmers from the central and northern regions. 
Research trials have since been carried out with the cooperation of scientists from two of India's agricultural universities, Govind Ballabh Pant University of Agriculture and Technology (GBPUAT) and Sardarkrushinagar Dantiwada University of Agriculture and Technology (SDUAT).

In a peer-reviewed paper on SYA, Pandey et al. (2015) wrote up and consolidated the results of several of these trials. One trial by the Directorate of Wheat Research in Karnal focused on the growth, productivity and quality of bread wheat in the growing season 2011-2012, on three adjacent parcels of land in Gagsina village, Karnal, Haryana. This trial compared four treatments: (1) organic farmyard manure plus yogic meditation (SYA), with (2) organic farmyard manure (ORG), (3) non-organic fertiliser (NPK) and (4) a control (CTL). The results are shown in Table 22.2 (Pandey et al., 2015) and have been tested for statistical significance. The results show a difference in performance between the SYA and the other treatments. SYA outperformed the organic and control in the categories of biomass, grain yield and grain weight. It did better than the NPK treatment in terms of grain weight and protein content, matched in terms of grain yield. The NPK treatment outperformed the others for biomass. While a one-season trial is not sufficiently robust, the indications are positive.

Another trial, carried out by SDUAT, focused on yields of wheat grain and stover (leaves and stalks), which were assessed over 3 years (one harvest per year) from 2009 to 2012, under treatments of (1) traditional organic with farmyard manure (ORG), (2) traditional organic + yogic farming (SYA) and (3) non-organic (NPK). In this trial, there was no control. As can be seen in Figure 22.1, for all 3 years and for both grain and stover, the non-organic treatment outperformed the rest. Apart from the first season, SYA outperformed the organic treatment. According to Ramsay (2012c), other results from this same trial showed higher amounts of iron, protein and vitamins in the SYA treatment compared to traditional organic and non-organic methods.

Pandey et al. (2015) summarised another experiment of SDUAT in which the quality (protein and oil contents) and quantity (haulm and oil yields) of groundnut were assessed over three harvest seasons (2009-2010, 2010-2011 and 2011-2012), with treatments of NPK, traditional organic and SYA practices. Although the yields of haulm and oil were significantly higher in the NPK-treated plots than in the traditional organic and SYA for all three harvest seasons, the protein and oil contents in the SYA treatments were higher than for the NPK and organic treatments.

A non-peer-reviewed study by Raval (ND) from Tolani College of Arts and Science in Adipur, India, published on the Brahma Kumaris website, also explores crop quality. This study assessed the protein, carbohydrate and energy values of SYA versus organic treatments of soybean. While the SYA treatments outperformed the organic in all three categories, little other information was provided regarding the details of the trial.

TABLE 22.2

\section{Trial of Bread Wheat over One Season, Comparing (a) SYA, (b) Organic and (c) Non-Organic Methods of Agriculture}

\begin{tabular}{|c|c|c|c|c|}
\hline Treatment & $\begin{array}{l}\text { Biomass } \\
\left(q^{\mathrm{a}} / \mathrm{ha}\right)\end{array}$ & $\begin{array}{c}\text { Grain Yield } \\
\text { ( } q^{\mathrm{a} / \mathrm{ha})}\end{array}$ & $\begin{array}{c}\text { 1,000-Grain Weight } \\
(\mathrm{g})\end{array}$ & $\begin{array}{c}\text { Grain Protein } \\
\text { Content }(\%)\end{array}$ \\
\hline Organic + yogic (SYA) & 81.31 & 31.46 & 44.28 & 9.13 \\
\hline Organic (ORG) & 63.28 & 22.78 & 41.70 & 9.78 \\
\hline Non-organic (NPK) & 94.59 & 31.81 & 41.74 & 8.03 \\
\hline Control (CTL) & 61.89 & 19.76 & 40.92 & 7.75 \\
\hline Results compared with $P=0.05(5 \%)$ & $3.69 \%$ & $2.48 \%$ & $1.49 \%$ & $0.51 \%$ \\
\hline $\begin{array}{l}\text { Source: Pandey et al. (2015). } \\
\text { a } 1 q \text { (quintal) }=100 \mathrm{~kg} \text {. }\end{array}$ & & & & \\
\hline
\end{tabular}




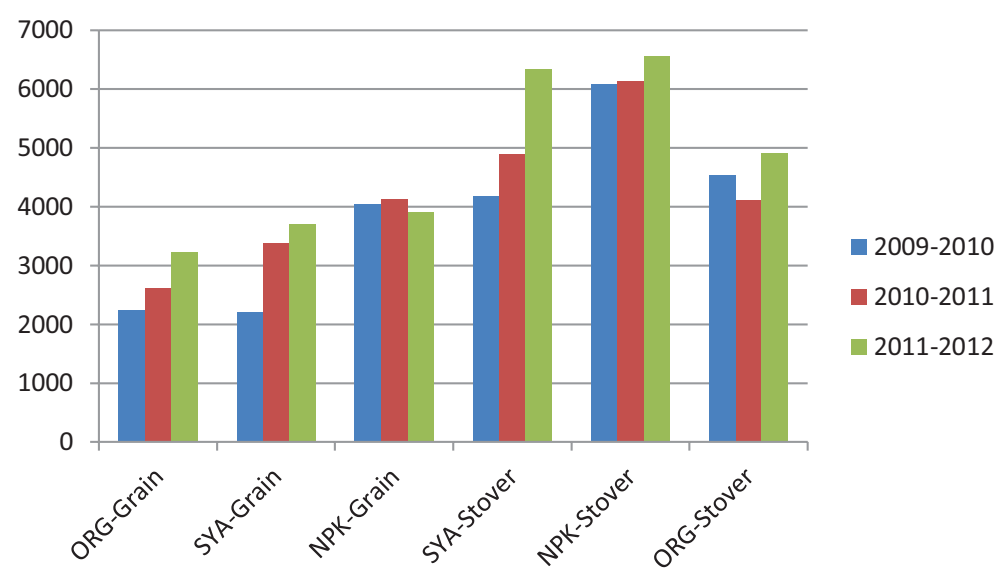

FIGURE 22.1 Bar chart showing yield ( $\mathrm{kg} / \mathrm{ha}$ ) of wheat grain and stover from SYA, organic and non-organic treatments. (Adapted from Pandey et al. (2015).)

\section{Farmers' Perspectives on the Impacts of SYA}

RDW has published at least 38 anecdotal reports of a qualitative nature from farmers on the benefits of adopting SYA, which were collected by Brahma Kumaris members (Ramsay, 2013b) and SDUAT university scientists (Patel et al., 2011). These benefits are summarised in Table 22.3.

Farmers in the group interview also identified improvements in the health and quality of their land and soil after abandoning the use of agrochemicals, including increased microbial load and activity and increased beneficial insect populations. In addition, there were fewer incidences of wild animals and pests causing crop damage. Livestock was reported to be more peaceful following the meditation practice. Customers were willing to pay more for their SYA produce, which they perceived to be of better quality.

The farm environment was reported to be more pleasant, joyful and refreshing, and these changes had also been noted by visitors. They felt their villages had become cleaner, more peaceful and unified politically, especially during elections. Farmers perceived their families as happier because the heads of the household (themselves) were more peaceful. They also noted fewer problems associated with addictions to smoking, alcohol, opium and other substances, since they had to abandon these practices. Fewer doctor's visits were reported, and one farmer claimed to have cured his paralysis problems after adopting SYA and eating more high-quality plant food. Farmers reported improved inner strength and higher self-esteem.

Most farmers planned to expand the SYA techniques to a larger area of their holdings. However, sufficient labour was a limitation, and the farmers were concerned that any labourers could affect the health of the crops if they were drinking and smoking. Some farmers in the group interview felt that the SYA farming was harder work since organic inputs were not always easily available whereas agrochemicals were. For example, the cow urine required as an ingredient for the traditional preparations should come from indigenous breeds, but in Gujarat, $90 \%$ of the cows are cross-bred. Hence, farmers felt they had to be seriously committed to the practices. The SYA farmers reported that 3 years was the transition period required to restore biodiversity to the land and soil. The Tapovan farm respondents noted that many farmers did not believe it possible to farm without agrochemicals and were afraid to try alternative methods as they expected lower yields. At this demonstration farm, the rationale was to explain that the higher quality produce led to higher market prices, and this combined with lower production costs (owing to the savings on agrochemical purchases) made SYA farming more profitable than non-organic farming. To help farmers adopt SYA, the RDW is facilitating a system of farmer-to-farmer networks, 
TABLE 22.3

\section{Key Quantitative and Qualitative Benefits of SYA, as Described by Farmers}

\section{Quantitative Benefits}

Increased crop yield

Increased crop nutritional content

Decreased costs of production

Increase in the price per kilo of product sold

Increased plant resilience

Decreased crop vulnerability to pests

Faster seed germination

Easy incorporation with other methods of sustainable agriculture such as sustainable rice intensification

\section{Qualitative Benefits}

\begin{abstract}
Improved family relations
Increased feeling of connection with livelihood

Increased sense of well-being and purpose

Increased sense of pride as a farmer

Improved relationships among farming communities

Reduction in emotions such as anger and frustration among farmers

Increase in emotions such as patience and forgiveness among farmers

Incorporates cultural and spiritual meaning into work life

Brings together disparate social sectors into a common purpose with wide-ranging benefits
\end{abstract}

Source: Ramsay (2013b) and Patel et al. (2011).

where farmers experiencing difficulties were put into contact via telephone with more experienced farmers.

In terms of spontaneous farmer-to-farmer dissemination, almost all SYA farmers in the group interview explained that their neighbours were sceptical when they initially adopted SYA but after some time would notice improvements in the quality of their produce of farm, which made them more curious to engage in SYA.

Online references show that SYA has also recently received attention at a national level with the Indian agricultural minister advocating that farmers adopt SYA (BBC, 2015). Outside India, SYA has also been adopted by an arable farmer in Italy who claims to have maintained profits and increased grain quality (Kebio EU, 2016).

\section{DISCUSSION: THE MIND-MATTER CONNECTION}

The published literature, farm visit and group interview all concur that the primary emphasis of SYA is positive human intention that is transmitted onto the farm, and this is carried out by trained farmer-meditators. The meditative practice, as well as the use of sound, is superimposed onto a foundation of standard organic practices that include the use of traditional preparations and remedies.

The mind-matter connection in the material realm and the effects of meditation on plant growth are supported by existing studies that attribute some scientific credibility to SYA claims (e.g. Dossey, 1998; Ducharme, 2007; Emoto, 2004; Loehr, 1959; Roney-Dougal and Solfvin, 2002, 2003; Radin and Nelson, 2000). These works are briefly reviewed below.

One of the earliest published experiments was undertaken on seed germination by Presbyterian minister and scientist Franklin Loehr (1959) who conducted two trials involving seeds and water. His results consistently indicated that positive prayer helped speed up germination and produced more vigorous plants, whereas negative prayer actually halted germination in some plants and suppressed growth in others. In another experiment, maize in a container receiving prayer water consistently sprouted a day earlier and had higher germination and growth rates than that in the other that received no prayer.

A meta-analysis by Radin and Nelson (2000) reviewed 40 studies carried out from 1959-2000 showing the impacts of mental intention focused towards a specific number, compared to a dice or random number generator (RNG). From a total of 515 RNG experiments by 91 researchers, the findings showed a statistically highly significant and repeatable mind-matter interaction effect in which 
the intention affected the outcome of the roll of the dice or RNG. The authors concluded from this study that the overall results could not be attributed to chance, selective reporting or variations in design quality. A well-known experiment made by Japanese scientist Masaru Emoto (2004) showed the effects of intent and words on water crystallisation patterns, and this has led to several publications and books which expound the potential implications for living organisms which are primarily composed of water. Ducharme (2007) published a doctoral thesis on an experiment in which positive and negative prayers were sent towards courgette seeds stored in Petri dishes in a greenhouse. The prayers were made by the researcher who was a trained alternative healer. The study found, compared to the control sample, a significant increase and decrease in germination rates and weights above statistical significance on the seeds receiving the positive and negative treatments, respectively. Roney-Dougal and Solfvin $(2002,2003)$ did two double-blind trials on two commercial organic farms in Somerset, UK, in which a trained healer blessed some of the lettuce seeds to test for germination and growth. The results showed that the seeds that were prayed for yielded an $\sim 10 \%$ higher crop yield and had less fungal and slug damage during the growing season than the control.

The many spiritual, physiological, psychological and emotional benefits provided by meditation have also been confirmed in numerous studies as summarised by Erickson (2016), and the practice of meditation itself has moved into the global mainstream culture for personal well-being (Pathath, 2017). SYA takes this further and applies meditative practices to crop growth and farm resilience (Ramsay, 2012a), and similar approaches that include a metaphysical dimension in agriculture have been advocated by Wright et al. (2017), Kieft (2006) and van Eijk (1998).

There are two main challenges with researching SYA. Firstly, in focusing on yield and productivity comparisons, the available research maintains the standard reductionist methodological approach while attempting to assess complex holistic systems that comprise both the physical and metaphysical. Nevertheless, the wider benefits of SYA are captured subjectively through the valuable anecdotal stories and literature of the SYA farmers, and this provides sufficient indication of differences between SYA, organic and conventional practices to encourage further research. Ramsay (2013b) recommends more targeted research on the topics of water absorption and retention, challenges of conversion from non-organic to SYA, the potential for SYA outside of the Brahma Kumaris community and India, differing farm scales and replicability with other forms of meditation.

The second challenge relates to differentiation between organic and SYA farming. It is possible that the reported economic benefits which appeared to be a result of the cost savings through both the non-purchase of agrochemicals and the selling of premium produce could be the result of the organic practices rather than the spiritual practices of SYA farming. Similarly, the environmental benefits could also be a result of switching from chemical to organic farming without the meditative practices having any impact. In addition, farming organically also requires conscious intention to switch from the mainstream approach - which is easier and less labour intensive, and thus, there could be intentional interference in organic as well as with SYA farming. Nevertheless committing to both the additional farm practices and the lifestyle changes of vegetarianism and abstinence (necessary to achieve a higher proficiency in Raja Yoga meditation) can be perceived as additional stringent requirements for the uptake of SYA farming and arguably involve an even stronger intention.

\section{CONCLUSIONS}

This chapter aims to provide an overview of SYA practices and investigate their effects. In order to achieve these objectives, a triangulated approach was deployed through a literature review, group interview and a visit to the SYA demonstration farm. Notwithstanding the lack of empirical verification, this provided rich data for the initial exploration of SYA as a farming system. While neutrality cannot be claimed - the small sample of farmers interviewed for this study had been selected by the Brahma Kumaris who were present during the group interview and who owned the demonstration farm visited - the author encountered what appeared to be a clear moral and spiritual integrity within the SYA movement. 
SYA superimposes a spiritual dimension onto standard organic practices, a dimension on which it places great emphasis. As a meditation-focused farming system, it offers synergies with the alternative agricultural movements, sharing common goals towards healthy food and community well-being. Such movements claim to be holistic, but to date, many of them have avoided or underemphasised the mind-matter dimension that is brought to the fore with SYA. SYA has achieved relatively good results at a local, national and international level in a very short (12 years) time period, and interest could spread further afield with the increased recognition and adoption of meditation practices originating from India. This study also highlights the psycho-social benefits of the meditation practice, which are incurred first by the farmer and then positively impact the entire farming family and community. This increased peace of mind - and fewer suicides ${ }^{1}-$ cannot be overestimated in the context of the plight of small farmers in India and other regions of the world.

\section{REFERENCES}

Aikenhead, G. and Michell, H. (2011) Bridging Cultures: Indigenous and Scientific Ways of Knowing Nature. New York, ON: Pearson Canada Ltd. Don Mills.

Apffel-Marglin, F. (2012) Subversive Spiritualities: How Rituals Enact the World. Oxford Ritual Studies Series. New York: Oxford University Press.

BBC (2015) India minister backs 'yogic' farming to 'empower seeds'. Available at: https://www.bbc.com/ news/world-asia-india-34254964 [accessed September 5th, 2020].

Bellwood, P. (2005) First Farmers: The Origins of Agricultural Societies. Malden, MA: Blackwell Publishing.

Brahma Kumaris (ND). Introducing ourselves. Available at: http://brahmakumaristhane.com/ [accessed August 10th, 2020].

Craven, J. and I'poyi, O. (2009) Indigenous epistemology and scientific method. Presented at the 16th Congress of the IUAES, Kunming, China July 26-31.

Dossey, L. (1998) Be Careful What You Pray for, You Just Might Get It: What We Can Do about the Unintentional Effects of Our Thoughts, Prayers, and Wishes. San Francisco, CA: HarperCollins.

Ducharme, L.J. (2007) The effects of intentional thought in close proximity or at a distance: Demonstrating the relation between mind and matter on seed germination. Ph.D. Thesis, Missouri: Holos University. http://www.holosuniversity.net/pdf/DuCharme_L_PDF\%20(1).pdf.

Eisenstein, C. (2013) The more Beautiful World Our Hearts Know Is Possible. Berkeley: North Atlantic Books.

Emoto, M. (2004) Healing with water. The Journal of Alternative and Complementary Medicine 10(1): 19-24.

Erickson, D.L. (2016) Integrating body, mind and spirit: An essay reviewing the physiological, psychological, and spiritual benefits of meditation. Journal of Transpersonal Research 8(2): 147-159.

IARC (2015) IARC monographs volume 112: Evaluation of five organophosphate insecticides and herbicides. Internal Agency for Research on Cancer (IARC). Rome: World Health Organization.

IPCC (2019) Global warming of $1.5^{\circ} \mathrm{C}$ : The intergovernmental panel on climate change. Available at: https:// www.ipcc.ch/sr15/ [accessed August 8th, 2020].

Kebio EU (2016). Spirituality and organic farming. Available at: https://www.kebio.eu/en/news/yoga-andagriculture.html [accessed August 10th, 2020].

Kieft, H. (2006) Quantum agriculture: Bridging frontline physics and intuitive knowledge of nature. In: Haverkort, B. and Reijntjes, C. (eds), Moving Worldviews, Reshaping Sciences, Policies and Practices for Endogenous Sustainable Development, pp. 209-218. Leusden: ETC/Compas.

Loehr, F. (1959) The Power of Prayer on Plants and People. Garden City, NY: Doubleday.

Pandey, S.T., Verma, O., Kewalanand, Pandey, D.S., Gill, S., Patel, J.C., Patel, G.N., Patel, D.M., Patel, B.T., Patel, B.B., Patel, D.S., Patel, I.S., Patel, R.N., Singh, N.K., and Thakur, D.M. (2015) Yogic farming through Brahma Kumaris Raja yoga meditation: An ancient technique for enhancing crop performance. Asian Agri-History 19(2): 105-122.

Patel, B.T., Patel, I.S., and Patel, M.M. (2011) Visit report for Brahma Kumaris Kolhapur, Maharashtra. SD Agriculture University. Available online: http://www.environment.brahmakumaris.org/images/ resources/Survey\%20Report.pdf.

Pathath, A.W. (2017) Meditation: Techniques and benefits. International Journal of Current Research in Medical Sciences 3(6): 162-168.

\footnotetext{
${ }^{1}$ One Indian farmer commits suicide approximately every 42 minutes (Prasad, 2019).
} 
Prasad, N.R. (2019) A review on the farmer suicides in India: An unsolved problem. Journal of Economic Policy and Research 14(1): 56-67.

Radin, D. and Nelson, R. (2000) Meta-analysis of mind matter interaction experiments: 1959 to 2000. Boundary Institute, Los Altos, California, and Princeton Engineering Anomalies Research, Princeton University, p. 11. Available online: http://citeseerx.ist.psu.edu/viewdoc/download?doi=10.1.1.385.3058\& rep=rep1\&type $=$ pdf [accessed August 10th, 2020].

Ramsay, T. (2012a) Systems approach to agriculture. Combatting Desertification, LEISA India, 14(4): 29-30.

Ramsay, T. (2012b) Awakening biodiversity consciousness. Statement for the Conference of the Parties to the Convention on Biological Diversity. Eleventh Meeting, Andhra Pradesh, Hyderabad, India. October 8-19, 2012. (Unpublished). Available online: https://www.researchgate.net/publication/239672387_ Awakening_Biodiversity_Consciousness (accessed August 10th, 2020).

Ramsay, T. (2012c) Yogic agriculture reaping rewards in India. Rioplus Business Magazine. Produced for: Rio+20, United Nations Conference on Sustainable Development, Rio de Janeiro, June 2012. pp. 118-119. Available online: http://www.academia.edu/1786497/Yogic_Agriculture_Reaping_Rewards_in_India (accessed August 10th, 2020).

Ramsay, T. (2013a) Sustainable yogic farming: Changing the lives and livelihoods of farmers. October 8th 2013. Available online: http://yogickheti.org/researchPapers/SYA_Living_in_Harmony_2013.pdf (accessed October 13th 2020).

Ramsay, T. (2013b) Sustainable yogic farming: Internal report. Tour of Maharashtra and Goa 2013. Brahma Kumaris at the United Nations, New York. Available online: https://www.researchgate.net/ publication/265172643_Informal_Report_-_SYA_Tour_India_September_2013 (accessed August 10th 2020).

Raval, K. (ND) A statistical analysis of the effect of yogic and organic fertilization on the Nutritive values of Soyabean. Department of Home Science, Tolani College of Arts \& Science, Adipur, Gujarat (Unpublished). Available online: http://www.yogickheti.org/researchPapers/Dr_Kiran_Raval_final_ paper.pdf (accessed August 10th, 2020).

RDW (2009) Perpetual yogic agriculture. Rural Development Wing. Rajyoga Education and Research Foundation and Prajapita Brahma Kumaris Ishwariya Vishwa Vidyalaya. Shantivan, Mount Abu: Omshanti Press. Available online: http://yogickheti.org/pdf/Book\%20English.pdf (accessed August 10th, 2020).

Roney-Dougal, S.M. and Solfvin, J. (2002) Field study of enhancement effect on lettuce seeds: Their germination rate, growth and health. Journal of the Society of Psychical Research 66: 129-143.

Roney-Dougal, S.M. and Solfvin, J. (2003) Field study of an enhancement effect on lettuce seeds: Replication study. Journal of Parapsychology 67(2): 279-298.

Santos, B.S. (2014) Epistemologies of the South. London: Routledge.

UNCCD (2011) Desertification: A Visual Synthesis. Bonn: UNCCD Publications.

UNCTAD (2013) Wake up before it is too late: Make agriculture truly sustainable now for food security in a changing climate. Trade and Environment Review. Geneva: United Nations Conference on Trade and Development.

van Eijk, T. (1998) Farming systems research and spirituality: An analysis of the foundations of professionalism in developing sustainable farming systems. Ph.D. Thesis, Wageningen: Wageningen Agricultural University. ISBN 90-5485-980-6.

Wright, J., Kieft, H. and von Diest, S. (2017) Quantum-based agriculture: The final frontier? In: Rahmann, G., Andres, C., Yadav, A.K., Ardakani, R., Babalad, H.B., Devakumar, N., Goel, S.L., Olowe, V., Ravisankar, N., Saini, J.P., Soto, G., and Willer, H. (eds), Innovative Research for Organic 3.0 - Volume 1. Proceedings of the Scientific Track at the Organic World Congress 2017, November 9-11 in Delhi, India. Braunschweig: Johann Heinrich von Thünen-Institut, 549 p., Thünen Rep 54, Vol. 1: 107-111. http://orgprints.org/32350/. 